\title{
Hub firms and the dynamics of regional innovation: case studies of Thales and Liebherr in Toulouse
}

\author{
Jean Pierre GILLY \\ LEREPS \\ Manufacture des Tabacs - Université Toulouse 1 \\ 21 allée de Brienne 31042 Toulouse Cedex 9 \\ gilly@univ-tlse1.fr \\ Damien TALBOT \\ GREThA \\ (UMR CNRS 5113) \\ Université Montesquieu Bordeaux IV \\ Avenue Léon Duguit 33608 Pessac Cedex \\ damien.talbot@u-bordeaux4.fr \\ Jean-Marc ZULIANI \\ LISST \\ (UMR CNRS 5193) \\ Université Toulouse 2 \\ 5, Allées A. Machado 31058 Toulouse Cedex 9 \\ zuliani@univ-tlse2.fr
}

In European Planning Studies, 2011, vol. 19, n¹2, pp. 2009-2024.

\begin{abstract}
Summary
The principal objective of this article is to offer an approach to the notion of hub firms using concepts from the Economy of Proximity. It shows that the specificity of the hub firm lies in its ability to combine technical and relational skills, allowing early involvement with, for example, an aircraft manufacturer in order to take part in the definition and the production of systems or sub-assemblies.

A particular characteristic of the hub firm is the way it develops linked organisational and geographical proximities which this article analyses in detail. In particular, such firms demonstrate the capacity to establish different types of organisational proximity according to whether they are co-ordinating with the architect-integrator or with sub-contractors, proximities sometimes reinforced by a temporary geographical proximity. When hub firms coordinate with industrial or scientific partners which help them conceive and master particular sets of skills, they often forge links based on geographical proximity in order to develop the innovations necessary for the acquisition and master of these in-house skills. These theoretical arguments are then tested in the cases of the hub firms Thales Aerospace and Liebherr Aerospace in the Toulouse aeronautical complex.
\end{abstract}

Keywords: hub firm / proximity / specification / innovation / aeronautics / Toulouse 


\section{Hub firms and the dynamics of regional innovation: the cases of Thales and Liebherr in Toulouse}

\section{Introduction}

The principal objective of this article is to offer an approach to the notion of hub firms using the concepts of the Economy of Proximity. Hub firms represent a new form of company organisation which is developing today in industry, and particularly in the aeronautical supply chain $^{1}$. In this industry, certain major suppliers are adapting to new constraints (modularisation of the production process, increased use of outsourcing, risk sharing, etc.) imposed by aircraft manufacturers, while the latter concentrate more and more on their core skills and on their roles of architect and final integrator of the aircraft. In order to make this adaptation, suppliers are seeking to develop and master a wider and wider range of skills. These skills are, on the one hand, technical, focussing on a homogeneous, strategic body of knowledge and, on the other hand, relational, involving the hub firm as the leader of a network of sub-contractors and partners taking part in the design and production of modules making up the aircraft. On the technical side, the interest of this approach for the hub firm lies in the establishment of technical and scientific innovation processes in order to master the specific skills necessary for the design and development of larger and larger projects entrusted to them by the aircraft manufacturers. On the organisational side, as shown by Thales and Liebherr in Toulouse, hub firms also undertake to supply components and sub-systems for the sub-assemblies which they are responsible for developing, at the same time supervising their final integration into the aircraft under construction.

The theoretical approach used in this study is based on the observation that geographical proximity can favour, in certain situations, economic relations between actors. Geographical proximity concerns objective conditions of location (Pecqueur, Zimmerman, 2004): it is not the inverse of measured distance. Distance, which may lead one to think of separation, is a quantitative expression of the relationship between two objects and/or two individuals. Proximity, on the other hand, is a qualitative judgement, necessarily subjective, of a small geographical distance. As a qualitative factor, it becomes a unit of social measurement with two fundamental values: "to be close to", "to be far from", forming the extremities of a

\footnotetext{
${ }^{1}$ This article is the result of a research contract co-financed by the Aquitaine and Midi-Pyrénées Regions in France and carried out between 2008 and 2010. The objective of this contract is to analyse the emergence of a new organisational form - the hub firm - in the fabric of the regional aeronautical industry.
} 
continuum (Torre, Rallet, 2005). However, the fact of feeling geographically "close" must not be interpreted as guaranteeing that a relationship will necessarily develop between the actors. A strong geographical proximity between actors represents a potential, latent resource. This resource will only be activated if the actors share, simultaneously, the same issues and a nongeographical proximity.

Such non-geographical proximity has institutional and organisational dimensions. Institutional proximity refers to the sharing of a set of perceptions, values and laws accepted as legitimate by the actors. These "rules of the game" allow organised relations between the actors (which brings us to the notion of organisational proximity): for example regulating collective learning processes in order to elaborate knowledge, setting up negotiation processes in case of conflict, organising power-sharing, legitimising choices or satisfying the interests of each party. And if rules condition organised relations, they are in turn produced by such relations, as in the example of organisations which produce and use rules permitting collective decisions to be taken.

Hub firms have the characteristic of being able to develop linked organisational and geographical proximities. In particular, such firms demonstrate the capacity to establish varied organisational proximities according to whether they are co-ordinating with the final client or with sub-contractors, proximities sometimes reinforced by temporary or permanent geographical proximity. Thus, when hub firms co-ordinate with industrial and/or scientific partners which help them conceive and master sets of skills, they develop links based on geographical proximity. In this case the hub firm develops regional innovations and learning methods necessary for the development of their in-house skills.

The article is in two parts: in the first section we present the proximities established by the hub firm with the architect-integrators and with sub-contractors in order to design and produce aircraft sub-systems, then in the second section we deal with the proximities established by the hub firm with industrial and scientific partners in order to build up specific skills. This theoretical approach will structure our analysis of the case studies of Thales Aerospace and Liebherr Aerospace in Toulouse. 


\section{The hub firm: the emergence of a new organisational form}

The hub firm, as a new organisational form, is part of a more general evolution in the organisation of industry. Even if it does not depend on major institutional changes (new values, perceptions, rules), it constitutes nevertheless an adaptation to the current changes in production processes in the aeronautical industry.

\subsection{The re-organisation of aeronautical activities and the emergence of the hub firm.}

The architect-integrators of the aeronautical industry (Bombardier, Embraer, Boeing and Airbus) have all undergone various restructuring programmes ( $c f$. for example Airbus's Power 8 and Power $8+$ plans) which have formed part of a profound mutation of the worldwide organisation of aeronautical activities. This mutation, which had already begun at the beginning of the millennium, may be characterised by:

- a re-centring of the activities of the aeronautical constructors on their core roles, that is to say pre-production (design, R\&D) and post-production (assembly of aircraft, sales and associated services such as training and technical assistance);

- the organisation of sub-contracting on the basis of the breaking down of the aircraft into technically homogenous subassemblies (modules). The in-depth nature of the studies required for the modularisation of the production process has given aircraft manufacturers new roles as architects and integrators of activities (Brusoni, Prencipe, 2001; Brusoni, Prencipe, Pavitt 2001; Frigant, Talbot, 2005);

- increasing outsourcing of those activities judged to be the least strategic to first- or second-tier sub-contractors with strong constraints in terms of price, quality and financial risk;

- the necessity for sub-contractors to provide a unified response (in particular through increased modularisation of production) to the varied requirements of the different principals (Airbus, Boeing, Bombardier, Embraer, etc.);

- a reinforcement of the role of major partners (main system manufacturers, equipment manufacturers) who are given the job of undertaking all the phases of production of an important component of the aircraft (design, development, industrialisation and manufacture). This might be a complete module (fuselage, doors, nacelles, motors, 
landing gear, piloting systems), specific equipment forming part of a module (cockpit equipment, air conditioning systems...) or relatively standardised equipment (video systems, electrical cabinets...);

- the emergence, among these major partners, of firms which play a new role, acting as industrial and technological pivots and intermediaries between architect-integrators, specialist partners and more traditional first- or second-tier sub-contractors.

These firms, which we henceforth qualify as hub firms, fit into the traditional framework of the hierarchical relationships of sub-contracting. Analyses in terms of strategic networks have already developed the idea of hub firms as core companies controlling a network (Jarillo, 1988), as brokers (Miles, Snow, 1992), as co-ordinating companies managing a value chain (Fulconis, Paché, 2005) or as focal companies organising the specialisation of members of the network in the sense of an asymmetry of powers and roles between the hub firm and the others (De Propis, 2001). If the concept of hub firm is not, therefore, new, we enrich it in this article by the introduction of work from the domain of the Economy of Proximity. In the case of the aeronautical industry, these firms have the characteristic of playing the role of coordinator between the architect-integrator and sub-contractors, particularly second-tier ones (Cagli, Kachidi, Levy, 2009). In this sense, they develop organisational proximities based on an ability to combine technologies and products coming from the actors that they co-ordinate, within a relatively stable global institutional framework. This framework may be equated to an institutional proximity, in the widest sense, which brings together all the actors involved in European civil aeronautics. For several decades, this framework has evolved little and is based mainly on market principles (Talbot, 2000). If the aeronautical industry remains a technological "shop-window" which competes at the national level and which brings beneficial spin-offs to the whole economy, thus justifying State intervention, it is imperative, at least for the civilian element, that it obeys the classical market rules applicable to other competitive sectors (like the automobile industry for example). Thus, in illustrating this institutional proximity which is specific to the whole European industry, cost control becomes a central value shared by companies and states because, in the context of strong competition, it conditions commercial success: today, a programme is perceived as a success if the aircraft sells. Consequently, in a market which is very attentive to price, radical innovations are generally abandoned in favour of gradual improvements of products in response to the requirements of clients. The central rule is that the objective of any improvement is to achieve a significant reduction for airlines in the cost of purchasing, operating and maintaining 
aircraft. The hub firm operates within this stable set of values, perceptions and rules shared by companies and governments. Our attention will, therefore, focus as a matter of priority on the organisational dimension of proximity developed by the hub firm.

For Cagli, Kechidi and Levy (2009) a hub firm possesses the technical skills specific to a particular field (avionics, aircraft structures...) and the abilities to form relationships which allow it to link the abilities of the other participants in the process of design or production. Thus the hub firm must organise modes of co-ordination with different actors in the supply chain and with scientific partners, which equates to developing distinct organisational proximities, depending on the partners and the activities concerned, sometimes associated with geographical proximity which is often temporary. In order to characterise organisational proximity, we propose to introduce a distinction between cognitive co-ordination and strategic co-ordination. Cognitive co-ordination consists of acquiring, conserving and passing on knowledge, know-how and experience, etc. Strategic co-ordination aims to give a coherence to conflicting interests, regulate conflicts which remain latent, prioritise problems, impose arbitration concerning, for example, the profits hoped for from the interaction, draw up compromises, and maintain a role in a range of relationships. The first type of co-ordination relates to a problem of sharing and transfer of knowledge, the second to a problem of regulation of productive relationships (Talbot, 2008) ${ }^{2}$, the whole forming part of an institutional proximity (values, perceptions, rules) widened to the mesoeconomic level, for example that of a network of firms or of a productive region. Thus:

- with the architect-integrator, cognitive co-ordination will prevail, based on a specification of products, as well as strategic co-ordination based on a relationship of service-provider in order to manage and adapt the final supply of complete systems and sub-assemblies. This co-ordination is sometimes reinforced by temporary - or exceptionally permanent - geographical proximity;

- with sub-contractors whose skills are not strategic and with industrial or engineering partners with specific skills, cognitive co-ordination will prevail which supposes technical mastery by the hub firm of the sub-contracted component and its interfaces, and strategic co-ordination as part of a classical market relationship;

- with research centres (laboratories and research institutes) cognitive links are built up based on scientific and technical exchanges whose objective is to develop, often in

\footnotetext{
${ }^{2}$ If we take the example of a company, the internal division of work relates both to a cognitive necessity to assign a content to tasks, but also to a political necessity to structure the actions of individuals whose status and interests are different - shareholders, directors, employees, trade unions - and to distribute wealth.
} 
common, the innovations necessary to the technological developments for the projects entrusted to the hub firm by the architect-integrator. The purely strategic issues of domination inherent in this type of (non-productive) relationship arise less acutely here (cf. part 2).

\subsection{Hub firm and architect-integrator: a relationship based on co-operation, specification of products and geographical proximity}

During the preparation of projects, the intervention of the hub firm is required earlier and earlier by the architect-integrator, in very early phases and alongside other competing major potential suppliers. These are the preparative phases, aiming at the pre-definition of projects based on confrontations and exchanges between the industrial actors involved. These highly organised exchanges tend to lead towards organisational proximities. As far as strategic coordination is concerned, the issue for the hub firm is to push more or less hard in the direction of its own interests in terms of the technical choices which are made. At the end of these more or less co-operative relational processes a hub firm is chosen as official supplier to the architect-integrator. As far as cognitive co-ordination is concerned, the exchanges undertaken with the aircraft manufacturer aim towards the common production of new knowledge and new know-how indispensable to the advancement of the project and to the joint development of a technical sub-assembly: in this case the term specification is applied. Such a process (Colletis, Rychen, 2004; Colletis, Pecqueur, 2004) characterises the ability of the participants to redeploy and combine their technological and industrial resources, and at the same time to create new ones as well as opening new technical-industrial pathways.

\subsubsection{Organisational proximity: strategic co-ordination based on a more co-operative relationship}

The hub firm coordinates strategically with the aircraft manufacturer by positioning itself in an important segment of the supply chain, thus appearing as a practically indispensable interlocutor because it possesses skills which are essential to the design and manufacture of major sub-assemblies. The hub firm shares this strategic position in the supply chain with one or two competitors, also likely to be called upon by the aircraft manufacturer.

In concrete terms, Thales Aerospace and Liebherr Aerospace have, while using different methods and timescales, applied a sustained strategy involving moving up the value chain in order to obtain a strategic role in that chain. The objective is thus to obtain as complete control as possible of both the design and the production - of avionics systems for Thales, and 
air management systems for Liebherr - which the aeronautical architect-integrators entrust to them. The Toulouse site of Thales Aerospace ${ }^{3}$ works on the software architecture of avionic systems. Becoming, with the A380 programme, one of Airbus' major suppliers, particularly in the area of Integrated Modular Avionics equipment (IMA), Thales Aerospace's ambition is to master the complete integrated architecture of complex flight systems: management of traffic and avionics. Thales thus appears as an indispensable systems manufacturer for Airbus.

Liebherr Aerospace is part of a Swiss industrial group ("FirmenGruppe Liebherr") with very diverse activities, particularly in aeronautics (air management systems, avionics and flight control systems). The Toulouse site, which has existed for a long time ${ }^{4}$, has specialised in the production of air management systems. The company has changed its status from that of supplier of sub-systems to that of a hub firm responsible for the analysis, definition and integration of complete systems dedicated to the intake of air and the pressurisation of cabins. This assumption of responsibilities, characteristic of the hub firm, may be seen in Liebherr's relationship with the world's third biggest aircraft manufacturer, the Canadian Bombardier, because in its dealings with Airbus, Liebherr Aerospace has still, for the moment, a more classical role as a supplier of components of technologically advanced sub-systems that Airbus assembles itself.

For hub firms, relational skills prove necessary at this stage, including mastery of negotiation processes, conflict management and the ability to find compromises. The issue for these hub firms is to be able to take the initiative with the objective of developing their credibility with Airbus by providing the latter with solutions, after having perhaps made criticisms or questioned the choices suggested by the aircraft manufacturer. The exchanges between hub firm and manufacturer allow a project to be refined iteratively after several loops whose objective is to determine progressively the work to be undertaken. In this way Liebherr Aerospace develops its relationship with Bombardier in five stages. In the first stage, called "Marketing Requirements", the manufacturer describes the needs of the market, while in the second stage ("Technical Requirements") Bombardier defines for its potential suppliers the specifications of the systems which it needs. Next comes the "Joint Technical Assessment Phase" in which hub firms and Bombardier review the different systems which it would be possible to adopt. The subsequent stages are more strategic. First, during a procedure known as the "Joint Conceptual Design Phase", the technical and cost objectives are defined in

\footnotetext{
${ }^{3}$ Formerly known as Thales Avionics.

${ }^{4}$ It goes back to the 1950's when the company was known as ABG SEMCA until it was bought by the Liebherr group in 1993.
} 
liaison with Liebherr Aerospace. The supplier chosen at the end of this phase then works with Bombardier and other specialist hub firms on the development of common solutions for the integration of the aircraft's different systems ("Joint Definition Phase"). The story is similar for the pre-project relationships developed by Thales Aerospace with Airbus: although to a large extent Thales masters the major technological innovations in-house, the aim of the initial co-operation is for Airbus to judge the skills and aptitudes of the hub firm. It does this by first inviting Thales to respond to a design competition on an avionic system to be created and integrated ("Request for Information"), then by evaluating Thales' proposals in terms of organising work on a "plateau" ("Request for Proposals"). In overall terms, the pre-project phases of strategic co-ordination lead to the development of co-operative relationships which are more or less balanced, and often go back over a considerable time, with the architectintegrator.

\subsubsection{Organisational proximity: cognitive co-ordination based on the specification of the product}

Still upstream of the supply chain, the hub firm takes part in the specification of assemblies or sub-assemblies with the architect-integrator. Specification aims at joint production of technical knowledge specific to a particular field (aircraft structures, avionics, landing gear, etc.). It also aims at the joint production of architectural knowledge which refers to the way in which components are integrated and linked to one another in a coherent whole (Henderson, Clark, 1990).

Because it supposes the production of common knowledge, specification requires significant cognitive co-ordination. Cognitive co-ordination consists of acquiring, conserving and transmitting knowledge, representations, know-how, experience, etc. This co-ordination involves a majority of Airbus' major suppliers, in particular of large avionic systems (Thales, Safran, Rockwell Collins...) or in the production of aircraft structures (Aérolia, Daher-Socata, Spirit...). Depending on their own skills, different aircraft manufacturers leave different degrees of latitude to hub firms for the development of design and specification. As far as relationships with Airbus are concerned, distinctions can even be observed between Thales and Liebherr. In terms of avionic equipment that it could potentially supply to the European aircraft manufacturer, Thales Aerospace is associated at a very early stage of the design phase. And even if Airbus' supply strategy is limited today to ordering equipment or avionic systems to do a precise job, Thales co-defines the possible systems, their technical objectives 
and their costs with Airbus. On the other hand, Liebherr becomes involved in projects further down the line: this can be explained by the fact that Airbus still has strong skills in the design of air management systems and appears to be reluctant to outsource such major works packages.

Smaller suppliers, working in specific domains, also take part in the joint design process. This is particularly the case with the Toulouse company Sogéclair, created in the 1960's, which has progressively become the engineering company responsible for the complete design of small and medium-sized pieces of structures for Airbus. Today it employs nearly 1,000 people, mostly in Toulouse. In the 2000's, Sogéclair worked in close liaison with Airbus to produce the initial definition of the nose fuselage floor of the A380, before being chosen to do the engineering for the project. The same situation has arisen for the design of the central shroud box of the A350. In both cases, Sogéclair's strategy has been to develop a close relationship with a manufacturing partner. In this way, the company has acquired the necessary recognition to be called upon by Airbus during the very early phases and then during the subsequent collaborative plateau phase.

\subsubsection{Relationship between organisational proximity and geographical proximity: teams} working on a plateau and the reinforcement of Toulouse sites

Beyond their active contribution to the specification of sub-systems and complete packages, hub firms conserve the classic privilege of working on a plateau in liaison with the aircraft manufacturers. This collaborative work associates architect-integrators and hub firms, whether the latter are simply engineering companies like Sogéclair or complete industrial supplier (engineering and manufacture) as in the case of Thales and Liebherr.

During these periods of collaborative work, the companies work towards a consolidation of the specifications of products and of systems before achieving a temporal convergence of all the contributions in order to prepare, under the co-ordination of the aircraft manufacturer, the integration of the different systems. If the geographical proximity of the companies is not essential (Liebherr's Toulouse site is a regular supplier of Bombardier in Montreal), temporary geographical proximity is necessary between the engineers of the different hub firms involved. In concrete terms, the plateau phase corresponds to a period of 4 to 6 months of shared work in situ with the architect-integrator, followed, for the hub firm, by internal development then a final integration phase led by Airbus which finalises the design process. 
Sometimes this geographical proximity becomes permanent. As a result of the first contracts obtained during the 1990's, in particular on the A320, A330 and A340 aircraft, or obtained on tender, in particular for the A380 and A400M, Thales Aerospace, which had hitherto had little presence in the Toulouse area, was led to reinforce its local workforce to form integrated Thales/Airbus teams and to specialise its site in the technical and commercial activities relating to avionics. This was the reason for the transfer of some of its teams from Vélizy (near Versailles) to Toulouse, in two stages in 1999 and 2001, coupled with the hiring of new staff, to bring the current workforce to 1,000. More recently, at Toulouse, Thales has further reinforced the co-ordinating capacities of a Strategic Business Unit (SBU) which works on the development of strategic lines of R\&T (Research and Technology), thus acting as the interface between the aircraft manufacturing clients and Thales' own Technological Business Units (TBU) ${ }^{5}$. For the same reasons, at the end of 2008 Liebherr transferred the activities of its Bavarian site in Lindenberg to Toulouse in order to establish a R\&T unit which manages transversally the projects developed by the company. This productive specialisation, linked to a move up the value chain, has led, over the last few years, to a reinforcement of the local capacity for design studies, tests and research and development which has been supported by a certain number of local institutions ( $c f$. part 2).

\subsection{Hub firms and sub-contractors: specification of products and commercial relationships}

Further down the supply chain, the hub firm plays in turn the role of architect, acting as an intermediary between the aircraft manufacturer and sub-contractors of tier 2 or higher. Once a particular sub-assembly has been jointly defined with the architect-integrator, the latter expects the hub firm, which remains its sole interlocutor, to supply that sub-assembly with the defined technical characteristics within the agreed timescale and price. It is the hub firm's decision whether or not, depending on its outsourcing strategy, to call on companies which are at the same level or further down the sub-contracting chain. The hub firm then has the role of leading, in cognitive and strategic terms, a network of sub-contractors and partner companies in place of the architect-integrator. In other words, the hub firm must be capable of

\footnotetext{
${ }^{5}$ TBUs are centres of technical development, distributed geographically depending on their specialised field (onboard computers in Meudon, cockpit technologies in Bordeaux, critical software in Toulouse...).
} 
taking on the role of architect, not, like the architect-integrator, for a whole aircraft, but for a sub-system.

\subsubsection{Classic sub-contracting relationships and industrial partnership links}

In strategic terms, because of the asymmetry of resources (financial, information, knowhow...), the hub firm is able to impose not only its own technical choices on its subcontractors, but also deadlines and prices depending on its own interests. This is a classical market relationship, even if it is preceded by a phase of technical co-operation. The hub firm thus defines, more or less strictly, the technical characteristics of the components of subassemblies and those of their interfaces over which it has control: the sub-contractors apply the technical specifications that are imposed upon them.

In cognitive terms, two categories of sub-contractors may be distinguished. On the one hand some sub-contractors possess only generic skills which are easily transferable. They are selected mainly on the basis of price and do not participate in the design of the product that they supply. In this configuration there is no specification between the hub firm and the subcontractor and theirs is a market relationship sensu stricto. On the other hand, certain subcontractors participate in the design of the sub-assembly for which they are responsible because they possess the material resources and the skills not only to produce it but to design it. Thus they hold specific assets which the hub firm, which is contracting work to them, does not hold. In this case, the term weak specification may be used between the hub firm and the sub-contractor inasmuch as the hub firm supplies the sub contractor with a set of precise technical specifications which the latter is obliged to apply. Only the interfaces which connect the sub-contracted sub-assembly to the sub-system are the subject of joint development.

Sometimes, this joint development goes beyond the interfaces and concerns the heart of the sub-system. The hub firm's strategy is then to procure specific skills from regional companies specialising in research and development and known as partner companies. This is particularly the case when a hub firm, responsible for the production of a complete on-board system, turns to a computer services firm for tasks including identifying the special characteristics and testing of software systems to be developed and supplied. These companies, often small, occupy a specialised technological niche and possess, in areas of innovation, know-how which is often little present in the hub firm. The latter then undertakes to associate these partner firms in the technical specification process, including using their expertise during the pre-project reflection phases preparatory to the plateau phase with the aircraft manufacturers. The combinatory approach of the hub firm may thus be judged on its 
ability to establish consortia and to work together with small, innovatory companies in terms of a design and innovation partnership.

\subsubsection{Strong geographical proximity with engineering partners; weak geographical proximity with manufacturing sub-contractors}

The geographical structure of sub-contractors matches that of specialisations and professions because whereas there is geographical proximity with a certain number of engineering service-providers and "technological partner" companies, manufacturing sub-contractors are increasingly dispersed across the globe.

By way of an example, the Toulouse site of Thales Aerospace relies essentially on local specialists in scientific and technical computing which also work in Toulouse in the space and automobile electronics industries. Geographical proximity in the monitoring of software development applied to highly critical systems is a means of reducing risks in terms of the technical and specific responses which are sought. However, questions of competitiveness and cost lead local software companies, under pressure from architect-integrators and hub firms, to resort to off-shoring (transfer of activities to North Africa, Eastern Europe, India and southeast Asia) for standard tasks such as coding and testing of programs.

As far as the sub-contracting of manufacturing - still important in aeronautical activities - is concerned, geographical proximity with the hub-firms which contract out work must be put in perspective: cost constraints lead Thales and Liebherr to seek tenders from firms dispersed not only all over France but all over the world. As well as an ability to create technology with local actors, hub firms in the aeronautical sector show, by their management of the interfaces with partners and sub-contractors, a marked aptitude to structure an industrial organisation at various geographical scales.

In the end, the constraint of geographical proximity is weak and may be circumvented by the mobility of individuals when face-to-face interactions are necessary, for example to finalise interfaces. The continual search for reductions in the cost of supplies leads contractors to select sub-contractors which are not in France or even in adjoining countries. In other words, geographical distance does not prevent interaction on condition that co-ordination tools be developed that compensate for this dispersion. Thus in this case organisational proximity predominates. 


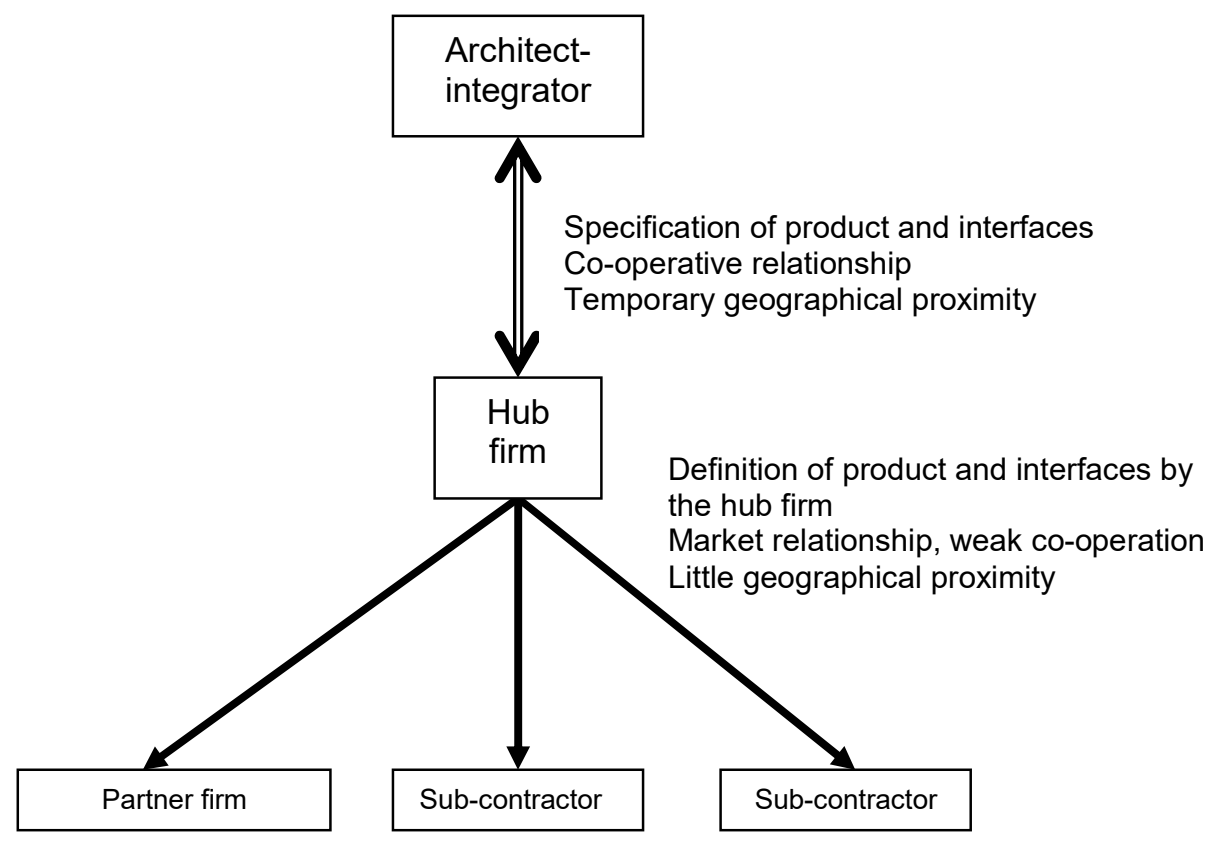

Diagram 1 The hub firm in the supply chain

\section{Hub firms and territorialized innovation processes}

The concept of the hub firm, as it has been introduced, corresponds rather to an industrial vision, because it is mainly centred on the capacity of this category of firm to manage the many and varied interfaces with other productive actors in terms of the new division of work which is developing in the contemporary economic system. It is now necessary to introduce another essential dimension of the hub firm, that is to say its involvement in territorialized technological innovation processes which constantly renew its own skills in terms of technologies, but also industrial design and the organisation of production.

\subsection{Territorialized innovation processes structured by relationships of proximity}

Processes of innovation may be generated either by networked productive forms whose members do not share any geographical proximity, or take place within territories defined as innovative: technological cluster, local innovation system, business and research cluster... 6 . Thus, multi-site companies construct two types of organisational proximity, the first making

\footnotetext{
${ }^{6}$ Numerous authors have shown that the fact of being geographically close facilitates innovation through the ease of exchanging knowledge by face-to-face interactions. This is particularly the case among researchers claiming to adhere to the Economy of Proximity. $C f$. for example Rychen and Zimmerman (2008) or Carrincazeaux, Grossetti and Talbot (2008). Moreover see also Cooke (2010).
} 
reference to modes of co-ordination without any geographical proximity, the second relating to geographical proximity within local territories. If the European aeronautical clusters (Toulouse, Hamburg, Filton, Broughton, Madrid...) develop relationships of innovation between each other due to the structuring action of an aircraft manufacturer like Airbus (Cooke, 2001; Lublinski, 2003; Hickie, 2006) it must be admitted that, paradoxically, the development of knowledge within these same clusters is relatively less intense (Cooke, Ehret, 2009; Warriner, Mullhern, 2009). The firms in this industry would appear to form geographically unrelated networks rather than regional ones, mobilising geographicallydispersed knowledge and skills in order to innovate. This shows that, contrary to the idea according to which co-localisation would systematically lead firms to innovate together, it is often the case that companies favour relationships with distant partners, rather than with their neighbours (Rallet, Torre, 2000). In effect, if geographical proximity remains essential for the transfer of knowledge, this constraint can be met by the mobility of individuals and/or temporary forms of proximity (plateau teams, meetings...) (Torre, 2008).

But the hub firm contradicts this first finding inasmuch as it can both be part of a cluster in order to take advantage of its local environment with its industrial, technological and scientific partners, at the same time maintaining connections with companies on a larger geographical scale. In this way it participates in territorialized processes of innovation and creation of specific technologies for a particular sector. The relationships generated by hub firms can also have a more inter-industry content, as is shown at Toulouse by the scientific collaborations undertaken between firms from distinct sectors of activity in order to develop new technologies with transversal applications (Zuliani, 2008). In this sense, a hub firm like Liebherr has chosen to consolidate its foothold in the aeronautical field while diversifying its fields of technological intervention with aircraft manufacturers: starting from an acquired basis of knowledge and know-how in air systems (pressurisation and conditioning), its recent activities have spread to new aspects of on-board energy management such as power electronics and the all-electric aircraft.. This strategy certainly requires sustained initiatives of research and development, including at national level through co-operation with another hub firm (in this case Thales), but this is only possible because among Liebherr's teams there is a cognitive aptitude for redeploying skills towards technological fields which are close or connected.

In all cases, an institutional proximity between local actors of different types (companies, research centres...) and from different industries has become essential to the success of collective, territorialized processes of innovation. The three categories of proximity - 
organisational, institutional and geographical - then interact and combine to build what is called, in generic terms, a technological cluster.

This union relies particularly on the combinatory skills of the hub firm. In its technical/ scientific dimension (and no longer only technical/industrial), this skill is expressed by interrelationships between companies (industrial and service) and research units (public and private) making up a technological cluster. Beyond its ability to combine products and/or technologies and to co-ordinate the actors who make them, the hub firm, in its most highlydeveloped form, embodies an organisational form which facilitates the circulation and above all the production of knowledge, know-how and technologies. This production is the result of multiple and varied co-operations that the hub firm organises between actors with different, if not even divergent approaches: companies, research centres, institutions... The hub firm is not the only actor in the cluster to organise such co-operation. The presence of intermediary structures (often set up by public institutions) allowing hub firms to meet local actors encourages collaboration. Such collaborations contribute both to the concretisation and development of the shared rules and common values which constitute an institutional proximity and to the construction of organisational proximity. The hub firm becomes one of the key actors in the cluster where it lies both at the heart of the dynamic of local technical/scientific organisation (organisational proximity) and at the centre of the institutional codes of conduct (institutional proximity) which orientate the behaviour of those actors which are geographically close.

Finally, the hub firm, at least in the aeronautical industry, may be distinguished by its ability to manage the interface between industrial organisation and regional creation of technologies. The hub firm proves to be capable of both:

- forming part of a process of innovation and creation of specific regional resources in conjunction with strategic partners: innovating small firms, research laboratories...;

- linking this regional process with a double process: on the one hand, a technological process internal to the company and on the other hand a process of specification with the architect integrator.

Diagram 1 should thus be enriched as follows: 


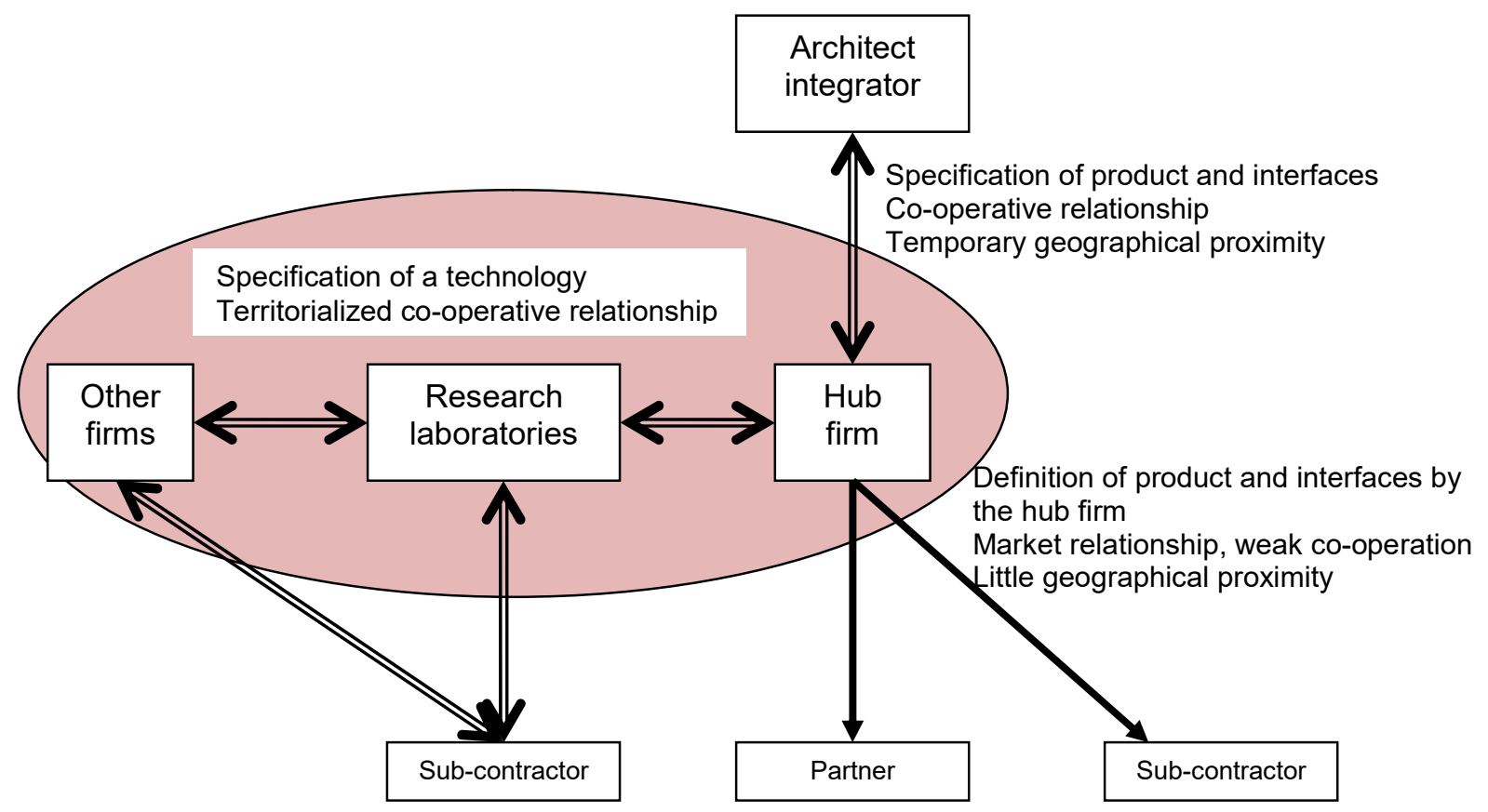

Diagram 2 Hub firms and territorialized innovation process

\subsection{Thales, Liebherr and territorialized innovation processes at Toulouse}

Faced with the perspective of the projects and technical modules entrusted to them increasing in size, Thales Aerospace and Liebherr Aerospace have intensified their collaborative practices with local actors in the fields of research and technology leading in the same way to territorialized dynamics of innovation.

As we have emphasised in the preceding section, Thales and Liebherr have both increased their capacity at the local level to organise and manage R\&T activities. First in order to respond to the demands of the processes of specification begun with the architect-integrators but also to forge relationships with other local actors in order to create new technological resources. In the latter case, the contractual involvement of the hub firms in research policies has been found to be significantly modified, through the increased density of relationships developed at a regional level, both with partner companies and with research institutes. Thales Aerospace has always developed an active participation in collaborative R\&T programmes both at national and European level ${ }^{7}$. This approach of turning to major support mechanisms

\footnotetext{
${ }^{7}$ For example the Victoria project managed by Thales and whose objective is to standardise flight calculators.
} 
for research and technology is characteristic of Thales, company considered for a long time as strategic in the French aeronautic and military complex.

The setting up in 2005 of the intermediary structure known as the "Aerospace Valley" Business and Research Cluster common to the Midi-Pyrénées and Aquitaine regions moves in the direction of a significant densification of local scientific relationships (organisational proximity) generated by the two hub firms. The collaborative practices of the latter fit, to different degrees, into the already existing relational architecture in Toulouse between science and industry (Zuliani, 2008). But the Business and Research Cluster, by establishing a regulatory framework for co-operation, allows the rules of the game to be fixed and thus allows an institutional proximity to be shared by local public and private actors (architectintegrators, hub firms, small sub-contractors, research laboratories, local authorities, etc.). This regulatory framework thus contributes to the regulation of the interactions operating in the Toulouse aeronautical cluster. This regulation takes the form, for example, of an orientation of research themes around strategic business units (SBUs) of which certain are initiated and co-ordinated by Thales or by Liebherr.

As soon as the Business and Research Cluster was formally announced, Thales Aerospace was the first to take on the co-ordination of an "SBU" ( $c f$. diagram 3 below). More than a simple project, it was a strategic line of applied research entitled "Security and safety of air transport", which corresponded to Thales' core field of activity (critical systems), while nevertheless involving other major local actors (Airbus, the DSNA (department of air navigation services), Thales Alenia Space) as well as technological partner companies. The issue for Thales was to add a "security and safety" activity which would allow the company to progress, in the cognitive sense, towards key technologies with the perspective of mastering, in the strategic sense, the widest possible range of cockpit systems and technologies. Liebherr in turn seized the opportunity presented by the "Aerospace Valley" Business and Research Cluster to strengthen its relationships with regional actors, mainly the Toulouse-based laboratory LAPLACE (Plasma and Energy Conversion Laboratory) and a few small technology companies by working on projects approved by the Business and Research Cluster, either as project leader or simply as a partner in the project ${ }^{8}$. Its future perspectives in research and technology are based on the energy issues of power electronics with the objective of developing the unifying theme of the all-electric aircraft.

\footnotetext{
${ }^{8}$ In 2008, Liebherr Aerospace co-led, with Safran, the SBU "Energy, motorisation/equipment, propulsion and environment", also acting as leader of an applied research project on surface treatment.
} 
Alongside the mechanisms set up by the Cluster, regional programmes also exist in which, for example, the State is associated with regional institutions, like the recent "Electra" project whose objective is to reinforce industry in Toulouse and the Midi-Pyrénées region around the theme of the all-electric aircraft. For the local hub firms, these mechanisms also contribute to the renewal of collaborative strategies with the aim of producing technology, first by bringing them closer to local innovative companies which could, in the example of Thales Aerospace, supply the latter with a niche skill in order to meet its objectives oriented towards mastery of extended modular avionics and cockpit systems. This approach is illustrated in Toulouse by the involvement, with Thales Aerospace, of two research-only companies which specialise in $\mathrm{man} / \mathrm{machine}$ interfaces and tactile interactions.

Beyond this, the Toulouse sites of Thales Aerospace and Liebherr Aerospace have each begun technical/scientific co-operation with other hub firms outside the Toulouse metropolis, either in order to diversify their fields of specialisation or in order to master cross-disciplinary technologies. The involvement of the hub firms in local networks is thus coupled with involvement in national and international networks. One of the characteristics of these hub firms is indeed to manage, from their Toulouse sites, their involvement in several major R\&T projects, be they national (for example CORAC (Advice on Research into Civil Aviation), composite materials for aircraft, the cockpit of the future and management of on-board data) or European (for example the SESAR and Clean Sky European research platforms). This ability to co-ordinate scientific and technical partnerships with innovative companies of different sizes and situated at different geographical scales, is, in effect, one of the specificities of the combinatory skills developed by hub firms in the aeronautical industry in the Toulouse region. 


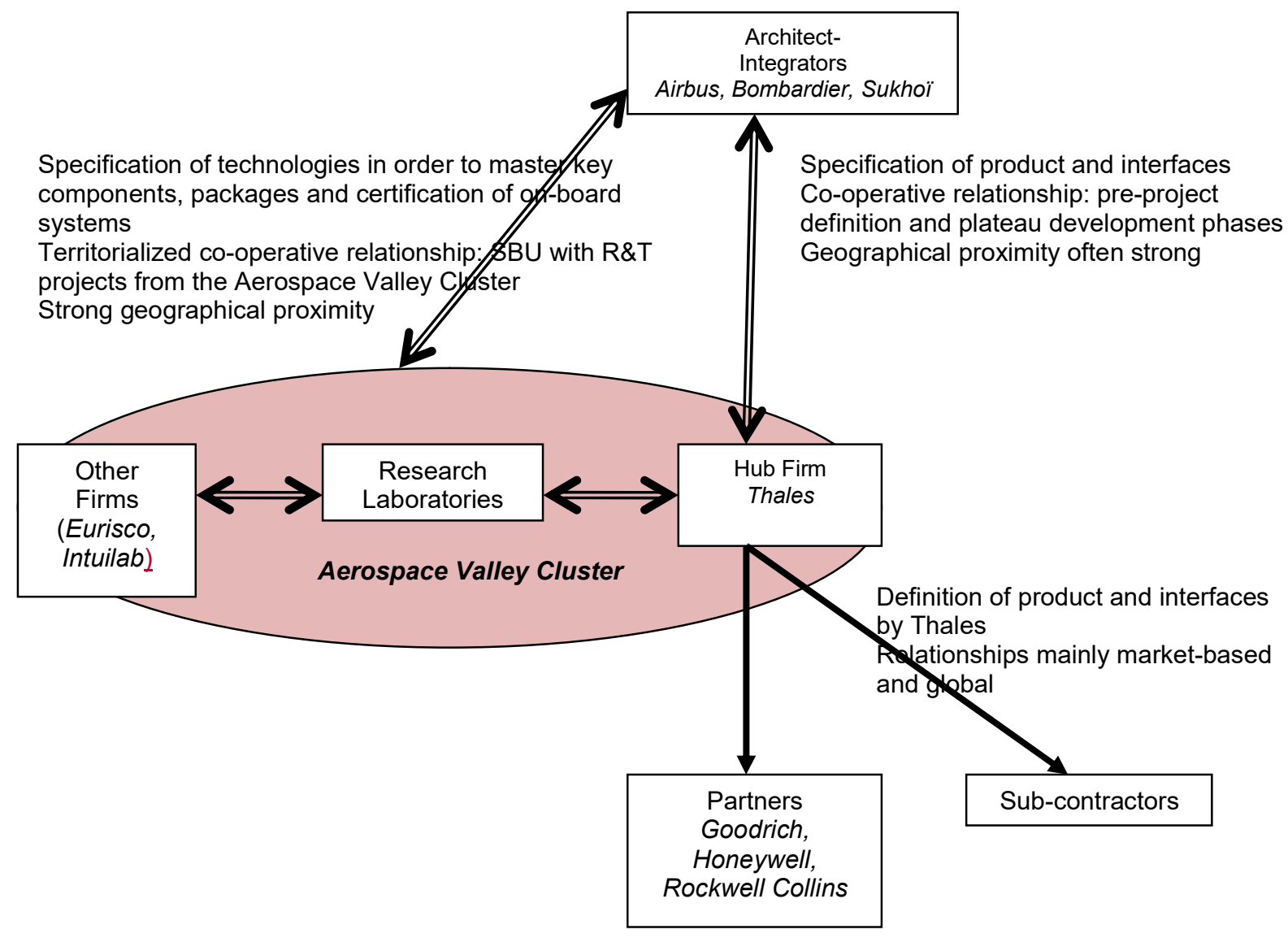

Diagram 3 Hub firm territorialized innovation process: Thales in Toulouse

\section{Conclusion}

The analysis of hub firms in the aeronautical industry has first brought to light their organisational ability to co-ordinate cognitively and strategically with the industry's various global architect-integrators. This pre-supposes that the hub firms have the ability to co-specify technical systems and sub-assemblies. Moreover, the hub firms exercise a co-ordinating role in order to ensure the participation of their subcontractors and industrial partners in their industrial projects. The management of the interfaces of industrial organisation also show, for the cases that we have studied, the ability of aeronautical hub firms to operate at distinct and related territorial scales, at local, national and international level, for the co-ordination of the different actors participating in their productive projects.

At the regional level, the hub firms also reveal an ability to create technology and to structure an organisation made up of dense networks of partner firms and research centres able to supply specific skills. Thales Aerospace and Liebherr Aerospace manage technical/scientific 
interfaces by creating and/or developing technologies with other regional industrial or scientific actors, which may or may not belong to the aeronautical industry. From these regional technical/scientific processes are born technological innovations which enrich both the specific competences and the organisational abilities of the hub firms to master more and more complete work packages.

In fact, the hub firm, through its ability to combine diverse resources and to favour the coordination of actors in the Toulouse cluster participates simultaneously in:

- the creation of new technologies and the specification of these resources with the architect-integrator, other strategic partner firms and certain sub-contractors;

- the restructuring of the organisation of sub-contracting and industrial partnerships and, beyond this, the emergence of a new distribution of work within the industry to which the hub firm belongs;

- the establishment of technological clusters through the construction of regional resources rooted in a network of relationships developed with local partners: industrial firms, service-providers, research centres and institutions. 


\section{References}

BRUSONI, S. and PRENCIPE, A. (2001) Unpacking the Black Box of Modularity: Technologies, Products and Organizations, Industrial and Corporate Change, vol. 10, n 1, pp. 179-204.

BRUSONI, S., PRENCIPE, A. and PAVITT, K. (2001) Knowledge Specialisation, Organizational Coupling, and the Boundaries of the Firm: Why Do Firms Know More Than They Make?, Administrative Science Quarterly, vol. 46, n4, pp. 597-621.

CAGLI, A., KECHIDI, M. and LEVY, R. (2009) Gestion stratégique de la supply chain et firme-pivot dans le secteur aéronautique, Revue Française de Gestion Industrielle, $\mathrm{n}^{\circ} 2$, juin 2009, pp. 236-251.

CARRINCAZEAUX, C., GROSSETTI, M. and TALBOT, D. (Eds) (2008) Clusters, proximities and networks, Special Issue of European Planning Studies, vol. 16, $\mathrm{n}^{\circ} 5$.

COLLETIS, G. and PECQUEUR, B. (2005) Révélation de ressources spécifiques et coordination située, Economie et Institutions, $n^{\circ} 6$ et 7, pp. 51-73.

COLLETIS, G. and RYCHEN F. (2004) Entreprises et territoires : Proximités et développement local, in B. PECQUEUR and J.B. ZIMMERMANN (Eds) Economie de Proximités, Hermès, Lavoisier, Paris.

COOKE, P. (2001) Regional innovation systems, clusters, and the knowledge economy, Industrial and Corporate Change, vol. $10 \mathrm{n}^{\circ} 4$, pp.945-974.

COOKE, P. (2010) Connecting local entrepreneurial ecosystems to global innovation networks: open innovation, double networks and knowledge integration, International Journal of Entrepreneurship and Innovation Management, forthcoming.

COOKE, P. and EHRET, O. (2009) Proximity and Procurement: A Study of Agglomeration in the Welsh Aerospace Industry, European Planning Studies, vol. 17, nº 4, pp. 549-567.

DE PROPIS, L. (2001) Systemic Flexibility, Production Fragmentation and cluster Governance, European Planning Studies, vol. 9, n․ pp. 765-782.

FRIGANT, V. and TALBOT, D. (2005) Technological Determinism and Modularity: Lessons from a Comparison between Aircraft and Auto Industries in Europe, Industry and Innovation, vol.12, $\mathrm{n}^{\circ} 3$, pp. 337-355.

FULCONIS, F. and PACHE, G. (2005) Piloter des entreprises virtuelles : un rôle nouveau pour les prestataires de services logistiques, Revue française de gestion, vol. $3, \mathrm{n}^{\circ} 156, \mathrm{pp}$. 167-186.

HENDERSON, R. and CLARK, K. (1990) Architectural innovation: the reconfiguration of existing product technologies and the failure of established firms, Administrative Science Quaterly, vol. 35, n¹, pp. 9-30.

HICKIE, D. (2006) Knowledge and competitiveness in the aerospace industry: the cases of Toulouse, Seattle and North-west England, European Planning Studies, vol. 14, n5, pp. 697-716.

JARILLO, J.C. (1988) On strategic networks, Strategic Management Journal, vol. 9, pp. $31-41$.

LUBLINSKI, A.E. (2003) Does Geographic Proximity Matter ?. Evidence from Clustered and Non-clustered Aeronautic Firms in Germany, Regional Studies, vol. 37, n 5, pp. 453-467.

MAZAUD, F. (2006), De la firme sous-traitante de premier rang à la firme-pivot. Une mutation de l'organisation du système productif, Revue d'Economie Industrielle, ${ }^{\circ} 113$, pp. 45-60.

MILES, R. and SNOW, C. (1992) Causes of failure in network organizations, Californian Management Review, vol. 34, $\mathrm{n}^{\circ}$ 4. pp. 53-72. 
PECQUEUR, B. and ZIMMERMANN, J.B. (2004) Introduction. Les fondements d'une économie de proximités, in B. PECQUEUR and J.B. ZIMMERMANN (Eds) Economie de Proximités, Hermès, Lavoisier, Paris.

RALLET, A. and TORRE, A. (2000) Is Geographical proximity necessary in the Innovation Networks in the Era of Global Economy? ,GeoJournal, vol. 49, pp. 373-380.

RYCHEN, F. and ZIMMERMANN, J.B. (Eds) (2008) Clusters in the Global Knowledgebased Economy: Knowledge Gatekeepers and Temporary Proximity, Special Issue of Regional Studies, vol. 42, n6, pp. 767-776.

TALBOT, D. (2000) The institutional dynamics at the origin of a new method of "local" administration: the relationship between Aerospatiale and its subcontrators, European Urban and Regional Studies, vol.7, $\mathrm{n}^{\circ} 3$, pp. 223-236.

TALBOT, D. (2008) Les institutions créatrices de proximités, Revue d'Economie Régionale et Urbaine, $\mathrm{n}^{\circ} 3$, pp. 289-310.

TORRE, A. (2008) On the Role Played by Temporary Geographical Proximity in Knowledge Transmission, Regional Studies, vol. 42, n6, pp. 869-889.

TORRE, A. and RALLET, A. (2005) Proximity and localization, Regional Studies, vol. 39, $\mathrm{n}^{\circ} 1, \mathrm{pp} .47-60$.

WARRINER, P. and MULHERN, C. (2009) From metal bashing to materials science and services: Advanced manufacturing and mining clusters in transition, European Planning Studies, vol. 17, pp. 120-134.

ZULIANI, J.M. (2008) The Toulouse cluster of on-board systems: a process of collective innovation and learning, European Planning Studies, vol. 16, n5, pp. 711-726. 